M. YAN, T. JIN, * Y. ISHIKAWA, T. MINATO, T. FUJITA, L.-Y. CHEN, M. BAO, N. ASAO, M.-W. CHEN, Y. YAMAMOTO (TOHOKU UNIVERSITY, SENDAI, JAPAN AND DALIAN UNIVERSITY OF TECHNOLOGY, P. R OF CHINA)

Nanoporous Gold Catalyst for Highly Selective Semihydrogenation of Alkynes: Remarkable Effect of Amine Additives

J. Am. Chem. Soc. 2012, 134, 17536-17542.

\section{Category}

Polymer-Supported

Synthesis

Key words

nanoporous gold

semihydrogenation

alkynes

amines

\title{
Nanoporous Gold Catalyst for the Selective Semihydrogenation of Alkynes
}

Significance: A nanoporous gold catalyst (AuNPore), which was prepared by dealloying a homogeneous $\mathrm{Au}_{30} \mathrm{Ag}_{70}$ alloy in nitric acid (70 wt\%), catalyzed the semihydrogenation of alkynes with organosilanes and water as the hydrogen source to afford the corresponding alkenes. The reaction of phenylacetylene with $\mathrm{PhMe}_{2} \mathrm{SiH}$ and water in DMF proceeded in the presence of $2 \mathrm{~mol} \%$ of AuNPore to give styrene as the sole product (method A: $35^{\circ} \mathrm{C}, 3 \mathrm{~h}, 96 \%$ yield). 1-Dodecyne underwent the semihydrogenation efficiently in acetonitrile with $50 \mathrm{~mol} \%$ of pyridine (method B: $80{ }^{\circ} \mathrm{C}, 8 \mathrm{~h}, 98 \%$ yield).
Comment: The catalytic ability of various catalysts was examined for the semihydrogenation of phenylacetylene: AuNPore (96\%), AuCl (18\%), $\mathrm{Au}_{30} \mathrm{Ag}_{70}$ alloy (0\%), PdNPore (54\%), and Pd/C (20\%). The authors proposed the reaction pathway including the generation of the $\mathrm{H}^{-}$on the AuNPore surface ([AuNPore-H] $]^{-}$) and pyridinium cation $\left([\mathrm{HPy}]^{+}\right)$which subsequently react with the alkynes to form the corresponding Z-alkenes. 


\section{Category}

Polymer-Supported Synthesis

\section{Key words}

\section{BINAP}

mesoporous catalysts

asymmetric hydrogenation

co-polymerization
Q. SUN, X. MENG, ${ }^{*}$ X. LIU, X. ZHANG, Y. YANG, Q. YANG, ${ }^{*}$ F. S. XIAO* (ZHEJIANG UNIVERSITY, HANGZHOU, CHINA)

Mesoporous Cross-Linked Polymer Copolymerized with Chiral BINAP Ligand Coordinated to a Ruthenium Species as an Efficient Heterogeneous Catalyst for Asymmetric Hydrogenation

Chem. Commun. 2012, 48, 10505-10507.

\section{Asymmetric Hydrogenation Using Polymer- Supported BINAP}

Preparation of chiral Ru/PCP-BINAP 5:<smiles>c1ccc(-c2ccc3ccccc3c2-c2c(P(c3ccccc3)c3ccccc3)ccc3ccccc23)cc1</smiles>

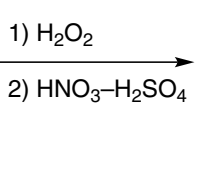

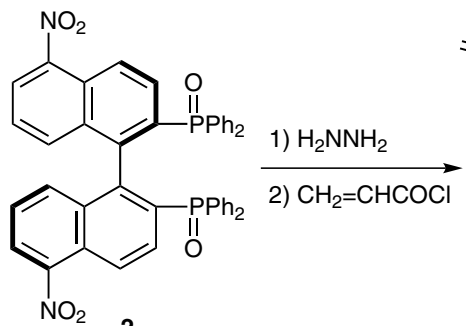<smiles>CCC(C)C(=O)Nc1cccc2c(-c3cccc(-c4ccccc4)c3-c3cccc4c(NC(=O)C(C)CCCC(C)c5ccc(C(C)C)cc5)cccc34)cccc12</smiles>
4 (PCP-BINAP)

Selected results:<smiles>[R]OC(=O)CC([R])=O</smiles><smiles>COC(=O)C[C@@H](C)O</smiles>

$7 a$ $94.6 \%$ ee $>99.5 \%$ conv.<smiles>COC(=O)C[C@@H](O)C(C)C</smiles>

$7 e$

$95.3 \%$ ee $>99.5 \%$ conv.<smiles>CCOC(=O)CC(C)O</smiles>

$7 \mathrm{~b}$

$95.1 \%$ ee $>99.5 \%$ conv<smiles>CC(O)CC(=O)OCc1ccccc1</smiles>
$7 f$

$95.4 \%$ ee $>99.5 \%$ conv

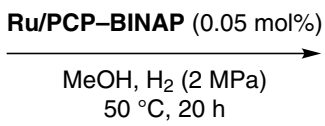

$50{ }^{\circ} \mathrm{C}, 20 \mathrm{~h}$<smiles>CCOC(=O)C[C@@H](O)c1ccc(OC)cc1</smiles>
$7 \mathrm{c}$
$97.7 \%$ ee $>99.5 \%$ conv<smiles>[R]OC(=O)C[C@@H]([R])O</smiles>

7<smiles>C=CC(=O)Nc1cccc2c(-c3c(P(=O)=P)ccc4c(NC(=O)C=C)cccc34)c(P(=O)=P)ccc12</smiles>

$\left[\mathrm{RuCl}_{2}(\mathrm{PhH})\right]_{2}$

Ru/PCP-BINAP

5<smiles>COC(=O)C[C@@H](O)CCl</smiles><smiles>[TeH]</smiles>

$94.3 \%$ ee $>99.5 \%$ conv.<smiles>C[C@H](O)CC(=O)OC(C)(C)C</smiles>

$7 \mathrm{~g}$ $99.0 \%$ ee $>99.5 \%$ conv.<smiles>CC(O)CC(=O)OC(C)C</smiles>

7h

$97.0 \%$ ee $>99.5 \%$ conv.
Significance: A polymeric BINAP-ruthenium complex (Ru/PCP-BINAP) was prepared by treatment of $\left[\mathrm{RuCl}_{2}(\mathrm{PhH})\right]_{2}$ with the mesoporous crosslinked polymeric $(R)$-BINAP ligand 4. Ru/PCPBINAP catalyzed the asymmetric hydrogenation of $\beta$-keto esters under hydrogen (2 MPa) to give the corresponding $\beta$-hydroxy esters $\mathbf{7 a - h}$ in $>99.5 \%$ conversion with 94.3-99.0\% ee.

SYNFACTS Contributors: Yasuhiro Uozumi, Yoichi M. A. Yamada, Heeyoel Baek Synfacts 2013, 9(1), $0108 \quad$ Published online: 17.12.2012 DOI: 10.1055/s-0032-1317918; Reg-No.: Y14712SF
Comment: Ru/PCP-BINAP was readily recovered and reused six times without significant loss of its catalytic ability $\left(1^{\text {st }}\right.$ reuse: $>99.5 \%$ conversion, $94.3 \%$ ee, $6^{\text {th }}$ reuse: $>99.5 \%$ conversion, $95.3 \%$ ee). 


\section{Asymmetric 1,4-Addition with a Chiral Calcium-Pybox Catalyst}

\section{Gategory}

Polymer-Supported Synthesis

\section{Key words}

asymmetric catalysis

Michael addition

calcium

continuous-flow synthesis

\section{SYNFACGDinh}

Flow conditions

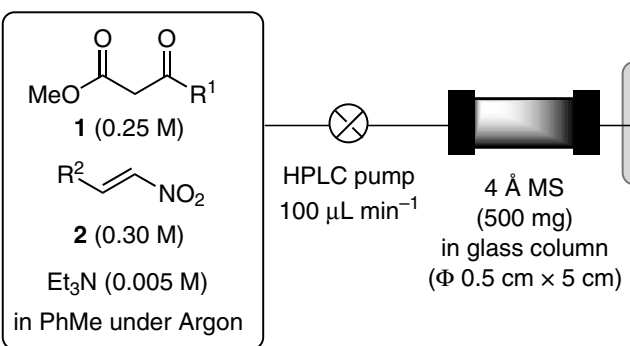

Selected examples:<smiles>COC(=O)C(C(=O)OC)C(C[N+](=O)[O-])c1ccccc1</smiles>

3a $(12-216 \mathrm{~h})$ $88-98 \%$ yield, $91-93 \%$ ee TON $=228$<smiles>COC(=O)C([C](C[N+](=O)[O-])c1ccc(F)cc1)C(=O)OC</smiles>
$94-95 \%$ yield, $90 \%$ ee<smiles>COC(=O)C([C](C[N+](=O)[O-])c1ccc(C)cc1)C(=O)OC</smiles>

3b $(12-18 \mathrm{~h})$ 90-92\% yield, $91 \%$ ee<smiles>COC(=O)C(C(=O)OC)[C@H](C[N+](=O)[O-])c1ccco1</smiles>

3f $(12-18 \mathrm{~h})$ $76-82 \%$ yield, $91 \%$ ee constant-temperature bath, $0{ }^{\circ} \mathrm{C}$

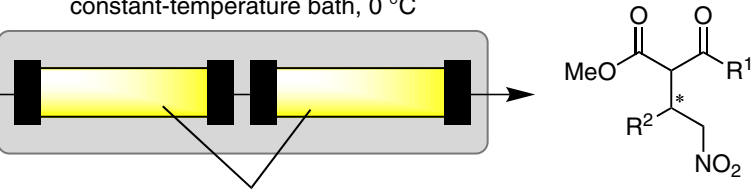

PS-Pybox $(750 \mathrm{mg} \times 2)$

$\mathrm{CaCl}_{2} \cdot 2 \mathrm{H}_{2} \mathrm{O}(375 \mathrm{mg} \times 2)$

in glass columns $(\Phi 1.0 \mathrm{~cm} \times 10 \mathrm{~cm})$<smiles>COC(=O)C([C](C[N+](=O)[O-])c1cccc(C)c1)C(=O)OC</smiles>

$3 c(12-18 \mathrm{~h})$ $81-88 \%$ yield, $95 \%$ ee<smiles>COC(=O)C(C(=O)OC)[C@H](C[N+](=O)[O-])C1CCCCC1</smiles>

$3 g(12-18 \mathrm{~h})$ $31-32 \%$ yield, $75-80 \%$ ee<smiles>COC(=O)C(Cc1ccc(OC)cc1)C(C(C)=O)C(=O)[O-]</smiles>

3d (12-18 h) $86-87 \%$ yield, $91 \%$ ee<smiles>COC(=O)C(C(C)=O)C(C[N+](=O)[O-])c1ccccc1</smiles>

3h (12-18 h) 95-96\% yield, $87-88 \%$ ee
Significance: A polymer-supported homochiral Pybox-calcium chloride complex catalyzed the asymmetric 1,4-addition of 1,3-dicarbonyl compounds $\mathbf{1}$ to nitroalkenes $\mathbf{2}$, to afford the corresponding adducts $\mathbf{3}$ in up to $98 \%$ yield and $95 \%$ ee under batch or flow conditions.
Comment: The flow system worked for 204 hours without significant loss of catalytic activity to give 3a in $95.5 \%$ yield with $92.0 \%$ ee on average. The total amount of product was $291.4 \mathrm{mmol}$ and the turn-over number (TON) reached 228.

sYNFACTS Contributors: Yasuhiro Uozumi, Yoichi M. A. Yamada, Aya Ohno Synfacts 2013,9(1), 0109 Published online: 17.12.2012 Dol: 10.1055/s-0032-1317727; Reg-No.: Y14412SF 


\section{Gategory}

Polymer-Supported Synthesis

\section{Key words}

amphiphiles

nanofibers

palladium nanoparticles

Suzuki-Miyaura coupling
M. A. Khalily, O. UStahuseyin, R. GARifullin, R. GenC, M. O. GUleR* (Bilkent UNIVERSITY, ANKARA, TURKEY)

A Supramolecular Peptide Nanofiber Templated Pd Nanocatalyst for Efficient Suzuki Coupling Reactions Under Aqueous Conditions

Chem. Commun. 2012, 48, 11358-11360.

\section{The Suzuki-Miyaura Coupling with Pd@Peptide}

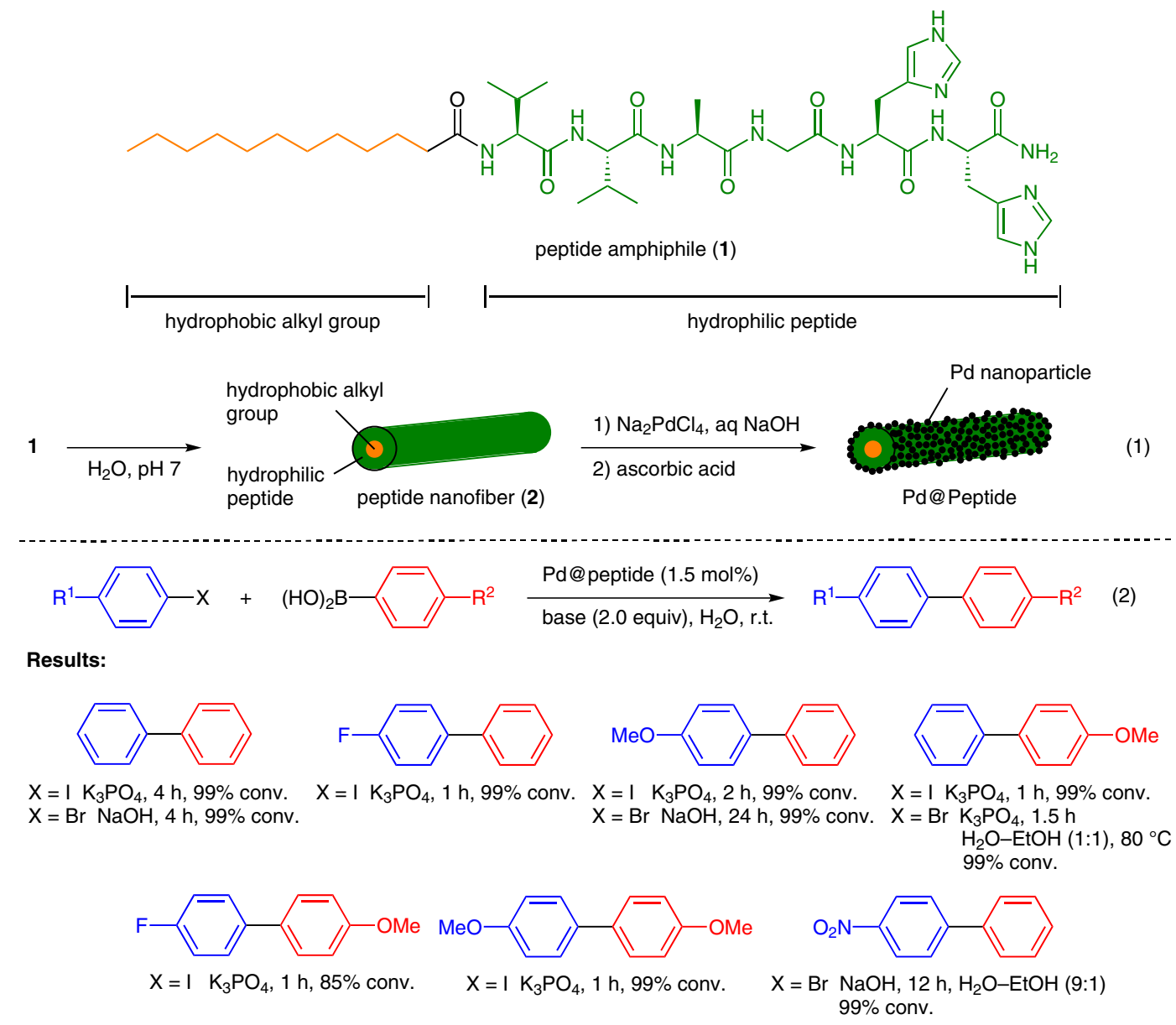

Significance: Palladium nanoparticles supported on peptide nanofiber (Pd@Peptide) were prepared by complexation of peptide nanofiber $\mathbf{2}$, prepared via self-assembling of peptide amphiphile $\mathbf{1}$, with $\mathrm{Na}_{2} \mathrm{PdCl}_{4}$ in aqueous $\mathrm{NaOH}$ followed by reduction with ascorbic acid (eq. 1). Pd@Peptide catalyzed the Suzuki-Miyaura coupling of aryl halides with arylboronic acids in water to give the corresponding biaryls in up to 99\% conversion (10 examples,

Comment: Pd@Peptide were characterized with TEM, SEM, XRD, and TGA. In the coupling reaction of bromobenzene and 4-methoxyphenylboronic acid, the catalyst was reused four times without significant loss of catalytic activity $\left(1^{\text {st }}\right.$ reuse: $97 \%$ conversion, $2^{\text {nd }}$ reuse: $97 \%$ conversion, $3^{\text {rd }}$ reuse: $97 \%$ conversion, $4^{\text {th }}$ reuse: $95 \%$ conversion). 
D. CANTillo, M. BAGHBAnZADEh, C. O. KAPPE* (KARL-FRAnZENS-University, GRAZ, AUSTRIA)

In Situ Generated Iron Oxide Nanocrystals as Efficient and Selective Catalysts for the Reduction of Nitroarenes

Using a Continuous Flow Method

Angew. Chem. Int. Ed. 2012, 51, 10190-10193.

\section{Reduction of Nitroarenes Using In Situ Generated Iron Oxide Nanocrystals}

Gategory

Polymer-Supported

Synthesis

Key words

iron

nanoparticles

nitroarenes

reduction

flow reaction

Reduction of nitroarenes using the batch system:<smiles>O=[N+]([O-])c1c[c-]ccc1</smiles>

Selected examples:<smiles>Nc1ccccc1</smiles>

$2 \min , 99 \%$ yield<smiles>COc1ccc(N)cc1</smiles>

6 min, $99 \%$ yield<smiles>Nc1ccc(Cl)cc1</smiles>

2 min, 99\% yield<smiles>COC(=O)c1cccc(N)c1</smiles>

6 min, $95 \%$ yield
$\mathrm{Fe}(\mathrm{acac})_{3}(0.25 \mathrm{~mol} \%)$

$\mathrm{N}_{2} \mathrm{H}_{4} \cdot \mathrm{H}_{2} \mathrm{O}$ (1.2 equiv)

$$
\mathrm{MeOH}
$$

$\mathrm{MW}, 150^{\circ} \mathrm{C}, 2-8 \mathrm{~min}$<smiles>Nc1ccc(Cl)c(Cl)c1</smiles>

2 min, 99\% yield<smiles>CC(=O)Nc1ccc(N)cc1</smiles>

$4 \mathrm{~min}, 99 \%$ yield<smiles>Nc1c[c-]ccc1</smiles>

(eq. 1)

20 examples 95-99\% yield

Continuous-flow reduction of nitroarenes:<smiles>[R]c1ccccc1[N+](=O)[O-]</smiles>

ca. $1.0 \mathrm{M}$ solution in $\mathrm{MeOH}$ (1.2 $\mathrm{M} \mathrm{N}_{2} \mathrm{H}_{4} \cdot \mathrm{H}_{2} \mathrm{O}, 2.5 \mathrm{mM}$ cat.)<smiles>Nc1ccccc1</smiles>

$$
\begin{gathered}
6 \mathrm{~mL} / \mathrm{min}, 150^{\circ} \mathrm{C} \\
\text { residence time: } 1.6 \mathrm{~min} \\
96 \% \text { yield }
\end{gathered}
$$

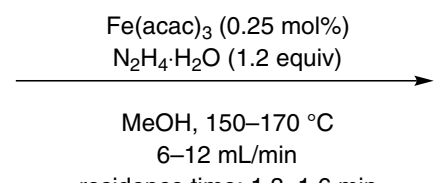

residence time: $1.3-1.6 \mathrm{~min}$<smiles>Nc1ccccc1Cl</smiles>

$12 \mathrm{~mL} / \mathrm{min}, 170{ }^{\circ} \mathrm{C}$ residence time: $1.3 \mathrm{~min}$ $95 \%$ yield<smiles>Nc1ccccc1O</smiles><smiles>Nc1cc(O)ccc1Cl</smiles>

$8 \mathrm{~min}, 99 \%$ yield

4 min, $99 \%$ yield<smiles>Nc1ccc2ncccc2c1</smiles><smiles>Nc1ccccc1-c1ccc(Cl)cc1</smiles>

$2 \mathrm{~min}, 99 \%$ yield
Significance: Iron oxide nanocrystals, generated in situ from $\mathrm{Fe}(\mathrm{acac})_{3}$ and hydrazine hydrate, catalyzed the reduction of nitroarenes with hydrazine hydrate under microwave conditions to give the corresponding anilines in 95-99\% yield (20 examples, eq. 1). In the reduction of nitrobenzene to aniline using the batch system, the catalyst was magnetically separated from the reaction mixture and reused seven times.
Comment: The reduction of nitroarenes was also performed using a continuous-flow system to afford the anilines in 95-97\% yield (eq. 2). The in situ generated iron oxide nanoparticles were characterized by XRD and HRTEM analyses. ICP-MS showed $7.9 \%$ iron leaching from the catalyst during the reduction using the batch system.

SYNFACTS Contributors: Yasuhiro Uozumi, Fumie Sakurai 


\section{Gategory}

Polymer-Supported Synthesis

\section{Key words}

gold nanoparticles titanium dioxide 1,2-disilanes alcohols
C. GRYPARIS, M. STRATAKIS* (UNIVERSITY OF CRETE, IRAKLION, GREECE)

Gold Nanoparticles-Catalyzed Activation of 1,2-Disilanes: Hydrolysis, Silyl Protection of Alcohols and Reduction of tert-Benzylic Alcohols

Chem. Commun. 2012, 48, 10751-10753.

\section{Silylation of Alcohol Derivatives with 1,2-Disilanes Catalyzed by $\mathrm{Au} / \mathrm{TiO}_{2}$}

(1)

Significance: Gold nanoparticles supported on titanium dioxide $\left(\mathrm{Au} / \mathrm{TiO}_{2}\right)$ catalyzed the silylation of water and primary, secondary, and tertiary aliphatic alcohols with 1,2-disilanes via Si-Si bond cleavage to give the corresponding silyl ethers in up to $>99 \%$ yield (eq. 1). When tertiary benzylic alcohols were used for the reaction, the reduction proceeded to afford the corresponding alkanes as the major products (eq. 2).
Comment: The authors previously reported the oxidative cycloaddition of 1,1,3,3-tetramethyldisiloxane to alkynes catalyzed by $\mathrm{Au} / \mathrm{TiO}_{2}$ (J. Am. Chem. Soc. 2011, 133, 10426). The catalytic activity of $\mathrm{Au} / \mathrm{TiO}_{2}$ for the silylation of water was superior to that of gold nanoparticles supported on other supports such as aluminum oxide $\left(\mathrm{Al}_{2} \mathrm{O}_{3}\right)$ and zinc oxide $(\mathrm{ZnO})$. 


\section{Annulation Reactions Catalyzed by Amberlite-Bound Hexafluorophosphate}

\section{Gategory}

Polymer-Supported Synthesis

\section{Key words}

catalysis

Amberlite

diamines

benzimidazoles

quinoxalines
Selected examples:<smiles>c1ccc(Cn2c(-c3ccccc3)nc3ccccc32)cc1</smiles>

$96 \%$ yield (r.t., $1 \mathrm{~h}$ )<smiles>COc1ccc(Cn2c(-c3ccc(OC)cc3)nc3ccccc32)cc1</smiles>

$88 \%$ yield (r.t., $2 \mathrm{~h}$ )

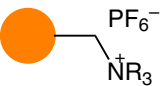

(eq. 1)

Amberlite- $-\mathrm{PF}_{6}$ (eq. 2)

$3 \mathrm{R}^{2}$

25 examples, $72-96 \%$ yield<smiles>O=[N+]([O-])c1ccc(Cn2c(-c3ccc([N+](=O)[O-])cc3)nc3ccccc32)cc1</smiles>

$79 \%$ yield (r.t., $8 \mathrm{~h}$ )<smiles>c1ccc(Cn2c(-c3ccncc3)nc3ccccc32)cc1</smiles><smiles>c1ccc2c(c1)nc(C1CCCCC1)n2CC1CCCCC1</smiles><smiles>C(=C/c1ccccc1)\Cn1c(/C=C/c2ccccc2)nc2ccccc21</smiles><smiles>Cn1cnc2ccccc21</smiles>
$68 \%$ yield (r.t., $8 \mathrm{~h}$ )

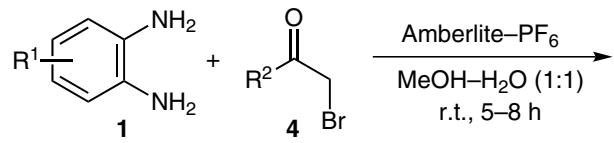

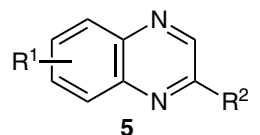

(eq. 3)
Significance: Amberlite resin-bound hexafluorophosphate (Amberlite- $\mathrm{PF}_{6}$ ) was prepared by treatment of Amberlite 900 with aqueous $\mathrm{NaPF}_{6}$ (eq. 1). In the presence of Amberlite- $\mathrm{PF}_{6}$, the annulation of phenylenediamines $\mathbf{1}$ with aldehydes $\mathbf{2}$ took place to give the corresponding benzimidazoles 3 (25 examples, 72-96\% yield).

SYNFACTS Contributors: Yasuhiro Uozumi, Makoto Nagaosa Synfacts 2013, 9(1), 0113 Published online: 17.12.2012 Dol: 10.1055/s-0032-1317917; Reg-No.: Y14612SF
Comment: The binding of hexafluorophosphate on Amberlite resin was confirmed by IR spectra (557 and $832 \mathrm{~cm}^{-1}$ ), though other characterizations were not given. Phenylenediamines 1 also reacted with $\alpha$-bromoketones 4 in the presence of Amberlite- $\mathrm{PF}_{6}$ to give the corresponding quinoxalines $\mathbf{5}$ via an aromatization step. 


\section{Category}

Polymer-Supported Synthesis

\section{Key words}

aldol reaction

organocatalysis

solvent-free
A. BAÑÓN-CABALLERO, G. GUILLENA, * C. NÁJERA* (UNIVERSIDAD DE ALICANTE, SPAIN) Cross-Linked-Polymer-Supported $N$-\{2'-[(Arylsulfonyl)amino][1,1'-binaphthalen]-2-yl $\}$ prolinamide as Organocatalyst for the Direct Aldol Intermolecular Reaction under Solvent-Free Conditions Helv. Chim. Acta 2012, 95, 1831-1841.

\section{Asymmetric Aldol Reaction with BINAM- Sulfonyl Polymeric Organocatalyst}

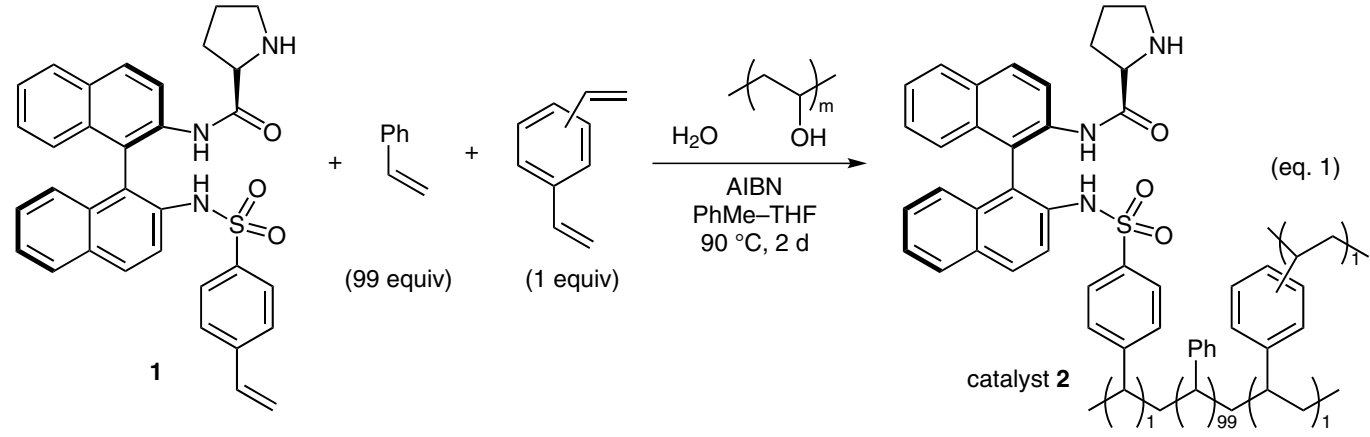<smiles>[R]CC([R])=O</smiles>

Selected examples:<smiles>O=C1CCCCC1[C@H](O)c1ccc([N+](=O)[O-])cc1</smiles>

3a $1 \mathrm{~d}, 88 \%$ yield $93 \%$ ee, anti/syn $=89: 11$<smiles>O=C1CCCCC1[C@H](O)c1cccc([N+](=O)[O-])c1</smiles>

3b $3 \mathrm{~d}, 82 \%$ yield $82 \%$ ee, anti/syn $=73: 27$

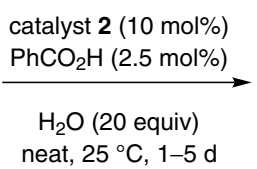

neat, $25^{\circ} \mathrm{C}, 1-5 \mathrm{~d}$<smiles></smiles>

9 examples up to $89 \%$ yield up to $95 \%$ ee<smiles>O=C1CCCCC1[C@H](O)c1ccccc1</smiles>

3c $3 \mathrm{~d}, 74 \%$ yield $85 \%$ ee, anti/syn $=60: 40$<smiles>O=C1CCOCC1C(O)c1ccc([N+](=O)[O-])cc1</smiles>

$3 d 3$ d, $69 \%$ yield $95 \%$ ee, anti/syn $=85: 15$<smiles>CC(=O)C[C@@H](O)c1ccc([N+](=O)[O-])cc1</smiles>

$3 e^{a} 2 d, 83 \%$ yield $56 \%$ ee $\left({ }^{a}\right.$ in the absence of $\mathrm{H}_{2} \mathrm{O}$ )<smiles>CC(=O)C[C@@H](O)c1ccc([N+](=O)[O-])cc1</smiles>

$3 \mathrm{f}^{\mathrm{a}} 5 \mathrm{~d}, 48 \%$ yield $72 \%$ ee<smiles>COC(C(C)=O)[C@H](O)c1ccc([N+](=O)[O-])cc1</smiles>

$3 \mathbf{g}^{\mathrm{a}} 3 \mathrm{~d}, 76 \%$ yield $87 \%$ ee, anti/syn $=83: 17$
Significance: The BINAM-sulfonyl polymeric organocatalyst 2 was prepared by the AIBNpromoted copolymerization of BINAM-derived sulfonamide 1, styrene, and divinylbenzene (eq. 1). Polymer $\mathbf{2}$ catalyzed the asymmetric aldol reaction of aliphatic ketones with aromatic aldehydes to give the corresponding aldol products $\mathbf{3}$ in up to $89 \%$ yield with up to $95 \%$ ee (9 examples, eq. 2 ).
Comment: In the aldol reaction of cyclohexanone with 4-nitrobenzaldehyde, the catalyst was recovered by filtration and reused six times with a slight decrease in its catalytic activity $\left(1^{\text {st }}\right.$ reuse: $90 \%$ yield, $90 \%$ ee, anti/syn $=87: 13,6^{\text {th }}$ reuse: $77 \%$ yield, 92\% ee, anti/syn = 86:16).

SYNFACTS Contributors: Yasuhiro Uozumi, Fumie Sakurai 


\section{Asymmetric Miyaura-Michael Reaction with Polymeric Rh/Ag Catalysts}

\section{Key words}

bimetallic nanoparticle catalysts

rhodium

silver

asymmetric 1,4-addition

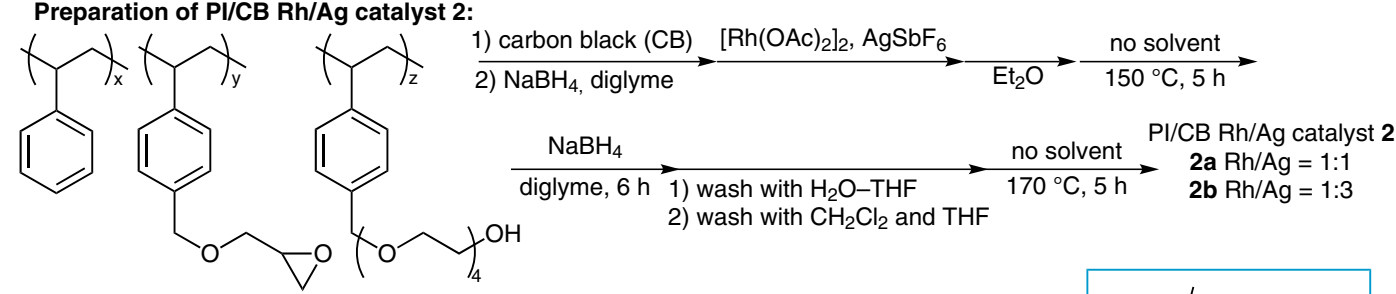

co-polymer 1 x:y:z = 29: 35: 36

Asymmetric 1,4-addition with $\mathrm{PI} / \mathrm{CB} \mathrm{Rh} / \mathrm{Ag}$ catalyst 2:

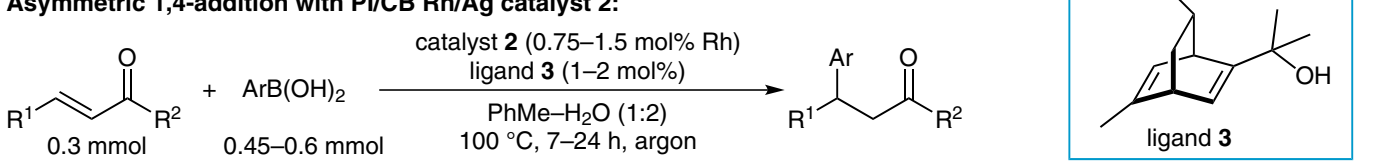<smiles>O=C1CCC[C@H](c2ccccc2)C1</smiles>

catalyst 2a quant., $98 \%$ ee<smiles>CC(C)(C)c1ccc([C@H]2CCCC(=O)C2)cc1</smiles><smiles>COc1ccc([C@H]2CCCC(=O)C2)cc1</smiles>

catalyst 2a $82 \%$ yield, $97 \%$ ee<smiles>Cc1ccccc1C1CCCC(=O)C1</smiles>

catalyst $2 \mathrm{a}$ $81 \%$ yield, $96 \%$ ee<smiles>O=C1CCC[C@H](c2ccc(F)cc2)C1</smiles>

catalyst 2a $87 \%$ yield, $98 \%$ ee<smiles>O=C1CC[C@@H](P)C1</smiles>

catalyst $\mathbf{2 a}$ $86 \%$ yield, $74 \%$ ee<smiles>Cc1cccc(C2CCCC(=O)C2)c1</smiles>

catalyst $2 \mathrm{a}$ $99 \%$ yield, $96 \%$ ee<smiles>COc1ccccc1[C@H]1CCCC(=O)C1</smiles>
catalyst 2a $95 \%$ yield, $93 \%$ ee<smiles>CC(CC(=O)c1ccccc1)c1ccccc1</smiles>

catalyst $\mathbf{2 b}$ $72 \%$ yield, $92 \%$ ee
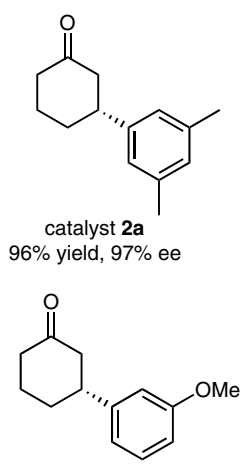

catalyst $\mathbf{2 a}$ $93 \%$ yield, $98 \%$ ee<smiles>CCCCCC[C@H](CC(C)=O)c1ccccc1</smiles>

catalyst $\mathbf{2 b}$ $70 \%$ yield, $95 \%$ ee
Significance: Polystyrene-based polymer-incarcerated bimetallic rhodium nanoparticle catalysts $\mathrm{Pl} / \mathrm{CB} \mathrm{Rh} / \mathrm{Ag} \mathbf{2 a}-\mathbf{b}$ were prepared from copolymer 1, carbon black (CB), $\left[\mathrm{Rh}(\mathrm{OAc})_{2}\right]_{2}$, and $\mathrm{AgSbF}_{6}$. Asymmetric 1,4-addition of arylboronic acids to enones was carried out with 2 and chiral ligand $\mathbf{3}$ to give the corresponding ketones in 70-99\% yield with 74-98\% ee without leaching of rhodium.
Comment: Catalyst 2a was reused 13 times for the reaction of phenylboronic acid with 2-cyclohexenone. After the $10^{\text {th }}$ use, the recovered catalyst was heated at $170{ }^{\circ} \mathrm{C}$ to regain its catalytic activity $\left(1^{\text {st }}-8^{\text {th }}\right.$ use: $>94 \%$ yield, $9^{\text {th }}$ use: $67 \%$ yield, $10^{\text {th }}$ use: $60 \%$ yield, $11^{\text {th }}-14^{\text {th }}$ use: $>90 \%$ yield, with $98 \%$ ee in all cycles).

SYNFACTS Contributors: Yasuhiro Uozumi, Yoichi M. A. Yamada, Yoshinari Yuyama

Dol: 10.1055/s-0032-1317915; Reg-No.: Y14312SF 


\section{Gategory}

Polymer-Supported

Synthesis

\section{Key words}

\section{catalysis}

iron

oxidation
W. KARUEHANON, C. SIRATHANYAROTE, M. PATTARAWARAPAN* (CHIANG MAI UNIVERSITY, THAILAND)

Poly(4-vinylpyridine-co-divinylbenzene) Supported Iron(III) Catalyst for Selective Oxidation of Toluene to Benzoic Acid with $\mathrm{H}_{2} \mathrm{O}_{2}$

Tetrahedron 2012, 68, 9423-9428.

\section{Polymer-Supported Iron(III) Catalyst for the Selective Oxidation of Toluene}

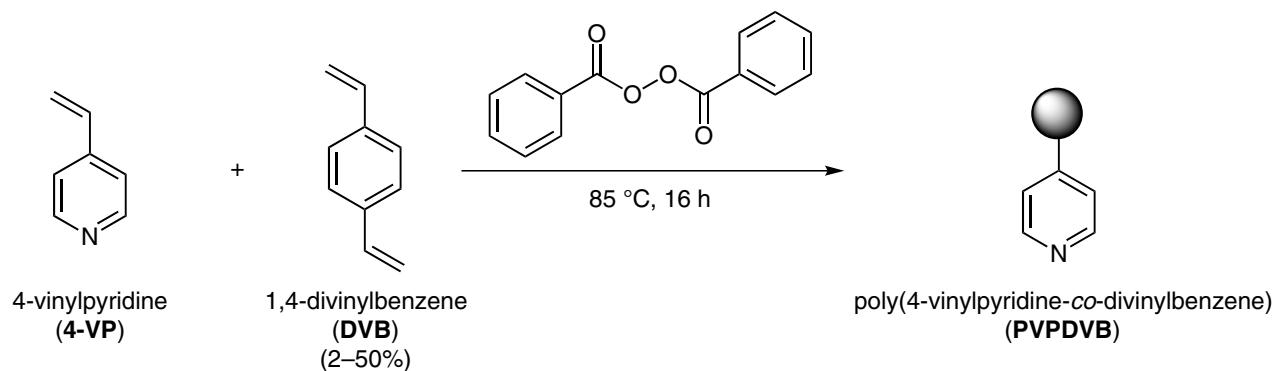

$\mathrm{FeCl}_{3} \cdot 6 \mathrm{H}_{2} \mathrm{O} / \mathrm{MeOH}$ reflux, $16 \mathrm{~h} \longrightarrow \mathrm{Fe}(\mathrm{III})-\mathrm{PVPDVB}_{2-50 \%}$

Fe(III)-PVPDVB ${ }_{2} \% 75 \%$ yield, $0.55 \mathrm{mmol} / \mathrm{g} \mathrm{Fe}$ $\mathrm{Fe}$ (III)-PVPDVB $6 \%$ 75\% yield, $0.54 \mathrm{mmol} / \mathrm{g} \mathrm{Fe}$ $\mathrm{Fe}(\mathrm{III})-\mathrm{PVPDVB}_{10} \% 96 \%$ yield, $0.41 \mathrm{mmol} / \mathrm{g} \mathrm{Fe}$ Fe(III)-PVPDVB ${ }_{25}$ 73\% yield, $0.52 \mathrm{mmol} / \mathrm{g} \mathrm{Fe}$ Fe(III)-PVPDVB ${ }_{50} \% 97 \%$ yield, $0.46 \mathrm{mmol} / \mathrm{g} \mathrm{Fe}$<smiles>Cc1ccccc1</smiles>

$35 \% \mathrm{H}_{2} \mathrm{O}_{2}(13.7 \mathrm{mmol})$ Fe-PVPDVB ${ }_{2-50 \%}(10 \mathrm{mg})$ $\operatorname{MeCN}(4 \mathrm{~mL}), 80^{\circ} \mathrm{C}, 6 \mathrm{~h}$ (1.46 mmol)

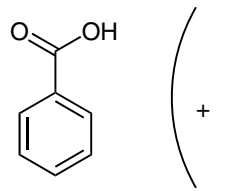<smiles>O=Cc1ccccc1</smiles><smiles>OCc1ccccc1</smiles><smiles>Cc1ccccc1CO</smiles>

Fe(III)-PVPDVB ${ }_{2} \% 73.0 \%$ conv., $91.0 \%$ selectivity to benzoic acid Fe(III)-PVPDVB ${ }_{6 \%} 78.8 \%$ conv., $90.2 \%$ selectivity to benzoic acid

Fe(III)-PVPDVB ${ }_{10} \% 89.7 \%$ conv., $91.2 \%$ selectivity to benzoic acid

Fe(III)-PVPDVB ${ }_{25} \% \mathbf{7 7 . 0} \%$ conv., $89.3 \%$ selectivity to benzoic acid

Fe(III)-PVPDVB ${ }_{50 \%} 77.9 \%$ conv., $88.3 \%$ selectivity to benzoic acid

Significance: Poly(4-vinylpyridine-co-divinylbenzene)-supported iron(III) catalysts bearing different amounts (2-50\%) of DVB cross-linker [Fe(III)$\mathrm{PVPDVB}_{2-50 \%}$ ] were prepared and applied to the oxidation of toluene with hydrogen peroxide (73.0-89.7\% conversion, 88.3-91.2\% selectivity to benzoic acid). The polymer-supported catalyst containing 10\% DVB [Fe(III)-PVPDVB $10 \%$ led to the selective oxidation of toluene to benzoic acid in $90 \%$ conversion with up to $96 \%$ selectivity under optimized conditions.
Comment: The catalytic activity of reused Fe(III)PVPDVB $_{10 \%}$ decreased due to leaching of iron ions from the polymer support. No oxidation of toluene occurred in the absence of the polymer-supported iron catalysts or in the presence of ironfree PVPDVB. The toluene oxidation with the homogeneous counterpart, $\mathrm{FeCl}_{3} \cdot \mathrm{H}_{2} \mathrm{O}$, resulted in lower substrate conversion ( $<58 \%$ ), while the reaction selectivity was as high as with the polymeric catalyst $(92 \%)$. 
B. KARIMi,* D. ElHAMifAR, O. YARI, M. KhORASANi, H. VALI, J. H. CLARK, A. J. HUNT (INSTITUTE FOR ADVANCED STUDIES IN BASIC SCIENCES, ZANJAN AND YASOUJ

UNIVERSITY, IRAN; MCGILL UNIVERSITY, MONTREAL, CANADA; UNIVERSITY OF YORK, UK)

Synthesis and Characterization of Alkyl-Imidazolium-Based Periodic Mesoporous Organosilicas: A Versatile Host for the Immobilization of Perruthenate $\left(\mathrm{RuO}_{4}^{-}\right)$in the Aerobic Oxidation of Alcohols

Chem. Eur. J. 2012, 18, 13520-13530.
Gategory

Polymer-Supported

Synthesis

Key words

oxidation

alcohols

carbonyl

compounds

ruthenium

organosilica

catalysis
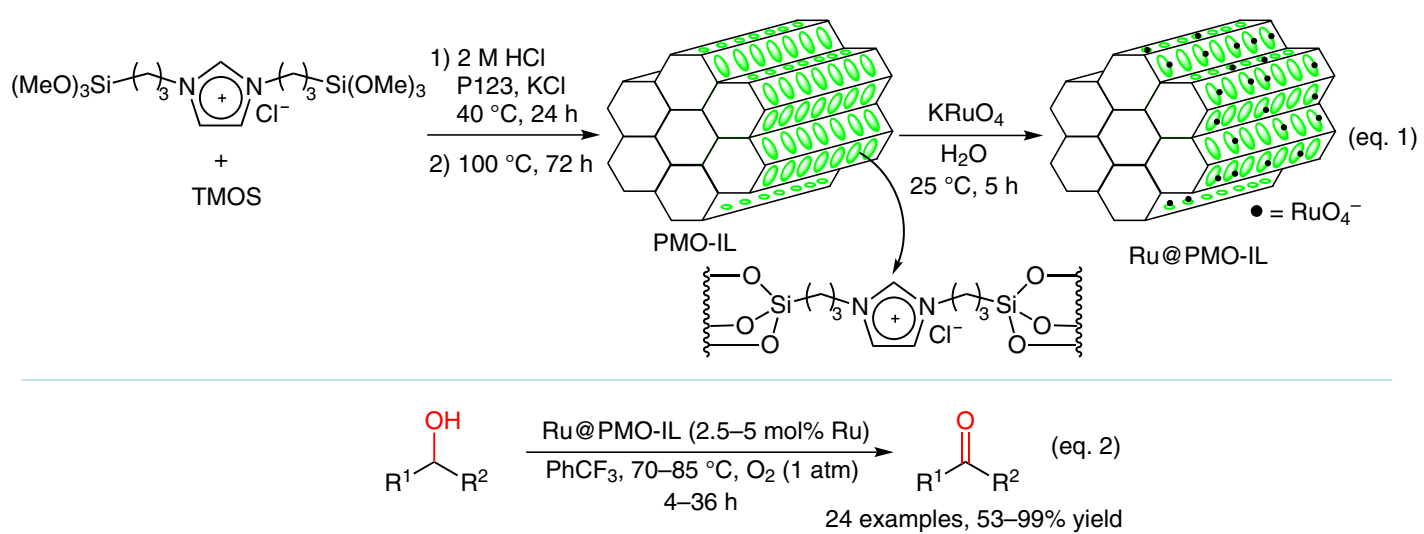<smiles>[2H]C=O</smiles>

$\mathrm{R}=\mathrm{Ph},>99 \%$ yield Tol, $>99 \%$ yield PMP, $>99 \%$ yield 4-i $-\mathrm{PrC}_{6} \mathrm{H}_{4}, 95 \%$ yield $4-\mathrm{ClC}_{6} \mathrm{H}_{4}, 95 \%$ yield $3-\mathrm{ClC}_{6} \mathrm{H}_{4}, 99 \%$ yield $2,6-\mathrm{Cl}_{2} \mathrm{C}_{6} \mathrm{H}_{3}, 70 \%$ yield $2-\mathrm{O}_{2} \mathrm{NC}_{6} \mathrm{H}_{4}, 87 \%$ yield $2,4-\mathrm{Cl}_{2} \mathrm{C}_{6} \mathrm{H}_{3}, 94 \%$ yield 2-furyl, $91 \%$ yield

3 -py, $78 \%$ yield

$\mathrm{CH}=\mathrm{CHPh}, 70 \%$ yield $\mathrm{CH}_{2} \mathrm{CH}_{2} \mathrm{CH}_{2} \mathrm{Ph}, 53 \%$ yield

$$
\begin{aligned}
& \mathrm{R}=\mathrm{Ph}, 96 \% \text { yield } \\
& \mathrm{HC}=\mathrm{CHPh}, 90 \% \text { yield } \\
& \left(\mathrm{CH}_{2}\right)_{5} \mathrm{Me}, 75 \% \text { yield }
\end{aligned}
$$<smiles>O=C1CCCCc2ccccc21</smiles>

$65 \%$ yield<smiles>COc1ccc(C(=O)c2ccc(OC)cc2)cc1</smiles>

$92 \%$ yield
24 examples, 53-99\% yield<smiles>O=C(C1CC1)C1CC1</smiles>

$95 \%$ yield<smiles>CCC(=O)c1ccccc1</smiles>

$91 \%$ yield<smiles>O=C(Cc1ccccc1)c1ccccc1</smiles>

$91 \%$ yield<smiles>O=C(c1ccccc1)c1ccccc1</smiles>

$>99 \%$ yield<smiles>CC1(C)C2CCC1CC(=O)C2</smiles>

$73 \%$ yield
Significance: Perruthenate was supported on ionic-liquid-based periodic mesoporous organosilica (Ru@PMO-IL) via the reaction of 1,3-bis(3-trimethoxysilylpropyl)imidazolium chloride with tetramethoxysilane, followed by treatment with $\mathrm{KRuO}_{4}$ (eq. 1). Ru@PMO-IL catalyzed the oxidation of alcohols in trifluorotoluene at $70-85^{\circ} \mathrm{C}$ under 1 atm of oxygen to give the corresponding carbonyl compounds in up to $>99 \%$ yield (24 examples, eq. 2).
Comment: The catalyst was recovered by centrifugation and subjected to recycling runs. ICP-AES analysis showed no significant ruthenium leaching ( $<1 \mathrm{ppm})$ under the reaction conditions. Nitrogen adsorption and TEM analyses of the recovered catalyst revealed no morphology change of the mesoporous structure. However, a slight loss of catalytic activity was observed during the recycling runs (for the oxidation of benzyl alcohol; $2^{\text {nd }}$ reuse: $99 \%, 4^{\text {th }}$ reuse: $89 \%, 5^{\text {th }}$ reuse: $\left.75 \%\right)$.

SYNFACTS Contributors: Yasuhiro Uozumi, Go Hamasaka 


\section{Gategory}

Polymer-Supported Synthesis

\section{Key words}

gold nanoparticles

UlImann homocoupling

aryl iodides

$\beta$-bromostyrene

A. MONOPOli,* P. COTUGNo, G. PALAZZO, N. DitARANTO, B. MARIANO, N. CiOfFi, F. CIMINALE, A. NACCI* (UNIVERSITÀ DEGLI STUDI DI BARI 'ALDO MORO', ITALY) Ullmann Homocoupling Catalysed by Gold Nanoparticles in Water and Ionic Liquid Adv. Synth. Catal. 2012, 354, 2777-2788.

\section{Ullmann Homocoupling in Water or Molten TBAOAc with Gold Nanoparticles}

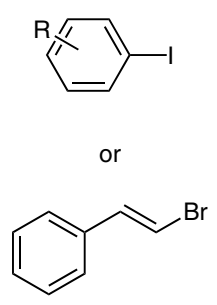

$(0.5 \mathrm{mmol})$

Selected examples:

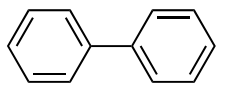

$7 \mathrm{~h}$

$98 \%$ yield (in aq TBAOH) $92 \%$ yield (in TBAOAc)

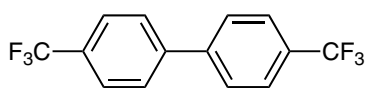

$15 \mathrm{~h}$

$70 \%$ yield (in aq TBAOH) $42 \%$ yield (in TBAOAc)
$\mathrm{Au}(\mathrm{OAc})_{3}(2 \mathrm{~mol} \%)$ glucose $(0.5 \mathrm{mmol})$

$\mathrm{H}_{2} \mathrm{O}(1 \mathrm{~mL})$, TBAOH (1.5 mmol) or TBAOAC $(0.5 \mathrm{~g})$ $90^{\circ} \mathrm{C}$

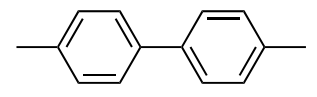

$7 \mathrm{~h}$ $97 \%$ yield (in aq TBAOH) $86 \%$ yield (in TBAOAc)

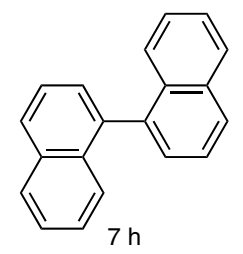

$97 \%$ yield (in aq TBAOH) $63 \%$ yield (in TBAOAc) up to $96 \%$ yield (10 examples)

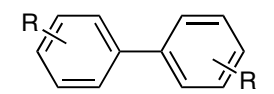

or
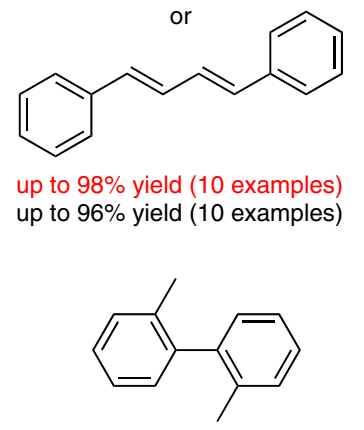

$15 \mathrm{~h}$

$85 \%$ yield (in aq TBAOH) $81 \%$ yield (in TBAOAc)

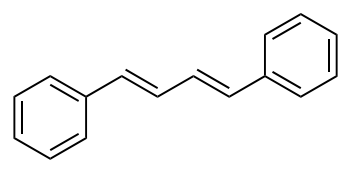

$15 \mathrm{~h}$

$91 \%$ yield (in aq TBAOH) $52 \%$ yield (in TBAOAc)
Significance: Gold nanoparticles, generated in situ from $\mathrm{Au}(\mathrm{OAc})_{3}$ and glucose, catalyzed the Ullmann homocoupling of aryl iodides or $\beta$-bromostyrene in aqueous tetrabutylammonium hydroxide (TBAOH) or in molten tetrabutylammonium acetate (TBAOAC) at $90{ }^{\circ} \mathrm{C}$ to afford the corresponding coupling products in up to $98 \%$ yield (10 examples) or in up to $96 \%$ yield (10 examples), respectively.
Comment: The gold nanoparticles were characterized with TEM, UVNis, DLS, and XPS. The particle size of the nanoparticles was about $1 \mathrm{~nm}$ in aqueous TBAOH and $20 \mathrm{~nm}$ in TBAOAc, respectively. The smaller nanoparticles showed higher catalytic activity because of their lager surfaces. 